\title{
Priority conservation areas for birds in El Salvador
}

\author{
Oliver Komar \\ University of Kansas Natural History Museum and Biodiversity Research Center, and Department of Ecology and Evolutionary Biology, \\ 1345 Jayhawk Boulevard, Lawrence, KS 66045-7561, USA.
}

(Received 11 December 2000; accepted 16 April 2002)

\begin{abstract}
El Salvador has the smallest protected areas system in Central America. High levels of habitat destruction and disturbance throughout the country make the reserve system especially important for conservation of biodiversity. I used complementarity approaches to assess the relative conservation importance of ten reserves in El Salvador. The principal criterion was presence of nationally threatened and endangered bird species. Additional criteria included residency status (resident species were more important than migratory non-breeding species) and regionally endemic species. Montecristo National Park was the most important area, with $42 \%$ of all nationally threatened birds present. El Imposible National Park, El Salvador's largest park (5000 ha), scored second, followed by Laguna El Jocotal wildlife refuge and Barra de Santiago wildlife refuge. In all, these four areas provide refuge for $83 \%$ of El Salvador's 268 nationally threatened bird species in less than 7600 ha of natural habitat. Because of small reserve sizes, all of El Salvador's threatened birds may need additional protection.
\end{abstract}

\section{INTRODUCTION}

El Salvador is a small country $\left(2100 \mathrm{~km}^{2}\right)$ situated in the heart of the northern Central America bioregion (southern Mexico, Belize, Guatemala, Honduras and northern Nicaragua). The country's rich soils and volcanic landscape have been widely altered by extensive agricultural and urban development during the nineteenth and twentieth centuries (Daugherty, 1972). Compared to other Latin American countries, relatively little natural habitat remained, but none the less El Salvador established a protected areas system in the 1970s. The system developed little during the 1980s owing to a civil war, but a surge in environmental awareness in the early 1990s, spurred by growth in ecotourism in nearby countries (especially Belize and Costa Rica), led to renewed conservation efforts (Secretaría Ejecutiva de Medio Ambiente, 1994). The environmental movement during the last decade has inspired widespread interest and support for wildlife and protected areas among the general populace. Nevertheless, El Salvador's protected areas system is by far the smallest in the region, in terms of both overall area and proportion of national territory (Rodríguez, 1998).

Although the protected areas are small, they are important for maintaining high levels of biodiversity for El Salvador and the northern Central America region.

All correspondence to: Oliver Komar, Tel: (785) 864-4065;

Fax: (785) 864-5335; E-mail: okomar@ku.edu.
The ten reserves considered in this paper are home to 237 locally threatened bird species (most are habitat specialists). Despite the country's small size and high population density (highest in Latin America with over 6 million human inhabitants), El Salvador has relatively high species richness. Over 520 species of birds have been reported (Komar \& Domínguez, 2001), 121 terrestrial mammals (Owen, Knox \& Baker, 1991), and 130 reptiles and amphibians (Dueñas, Wilson \& McCranie, 2001). Because of its small size and extensive deforestation, El Salvador is frequently considered of little importance for global-level biodiversity conservation. However, the country contains some natural resources of global significance. New species are still being described (e.g., Kilian \& Smalla, 2001), some of which may be completely restricted to the country. Little biological research has been undertaken (Winker, 1998; Johnson, 2001), and the extent and value of El Salvador's biological resources is still poorly known (Ministerio de Medio Ambiente y Recursos Naturales, 2000). Six regionally threatened ecoregions occur in El Salvador (Dinerstein et al., 1995), including five forest ecosystems of high conservation priority at a regional scale, and one of moderate conservation priority. They are Central American Montane Forests, Central American Pine-Oak Forests, Central American Dry Forests, Sierra Madre de Chiapas Moist Forest, Gulf of Fonseca Mangroves and Northern Dry Pacific Coast Mangroves, the latter best represented by the extensive Jiquilisco Bay mangroves in El Salvador. These eco- 
systems occur globally over a relatively small area on the Pacific slope of Central America.

With limited financial resources available for conservation in El Salvador, it would be useful for maximum efficiency to base conservation action on biological data. I conducted the present analysis to identify protected areas most important for the conservation of avian diversity, such that conservation agencies working in El Salvador could prioritize the allocation of budgets among the protected areas. I used only birds because sufficiently complete species lists for other taxa were not available. I based the analysis on nationally threatened and regionally endemic bird species (rather than overall species richness) because the primary goal of conservation is to prevent extinction of species. To include all species would bias reserve selection towards sites with large numbers of common, widespread species that occur in areas with high levels of habitat disturbance. Only one bird species in El Salvador is globally endangered (Hilton-Taylor, 2000), so using globally threatened species for the analysis would not have been useful. Williams et al. (1996) and Dobson et al. (1997) argued that a complementarity scheme was the most effective way to plan conservation, as it does not depend on subjective indices, and identifies areas where conservation action is most needed to protect a regional biota.

\section{METHODS}

I included in the analysis the ten protected areas (Fig. 1) for which reasonably complete bird lists have been prepared by experienced observers (Komar \& Herrera, 1995; Ramírez-Sosa \& Komar, 1996; Komar, 2000; N. Herrera, unpubl. data; O. Komar, unpubl. data). These are the largest protected areas in the country (Table 1), and have park guards, signage and recognition by Salvadoran society.

I identified conservation priorities for the reserves using an iterative, heuristic complementarity algorithm (Kirkpatrick, 1983; Williams et al., 1996; Peterson, Ball \& Brady, 2000a; Peterson et al., 2000b), in which reserves were selected (prioritized) based on the number of additional species of threatened birds protected by conserving the reserve. I used a list of 268 threatened or endangered bird species (Komar \& Domínguez, 2001) modified from a similar list (Komar, 1998) that included habitat specialists (species sensitive to habitat destruction), species suspected of population declines due to pollution or water contamination, or species subject to excessive hunting or commercialization. The presence/absence of threatened species in each protected area is given in Appendix 1. Species not likely to be regular components of a local avifauna, but nevertheless reported, were considered absent. The algorithm has four steps: (1) Select the reserve that protects the greatest number of threatened species. (2) Of the remaining reserves, select the one that adds to the system the most additional threatened species. (3) In the case of two reserves contributing the same number of additional species (a tie for step 2), I used as a second criterion residency status, considering adding threatened breeding residents to be more important than adding non-breeding

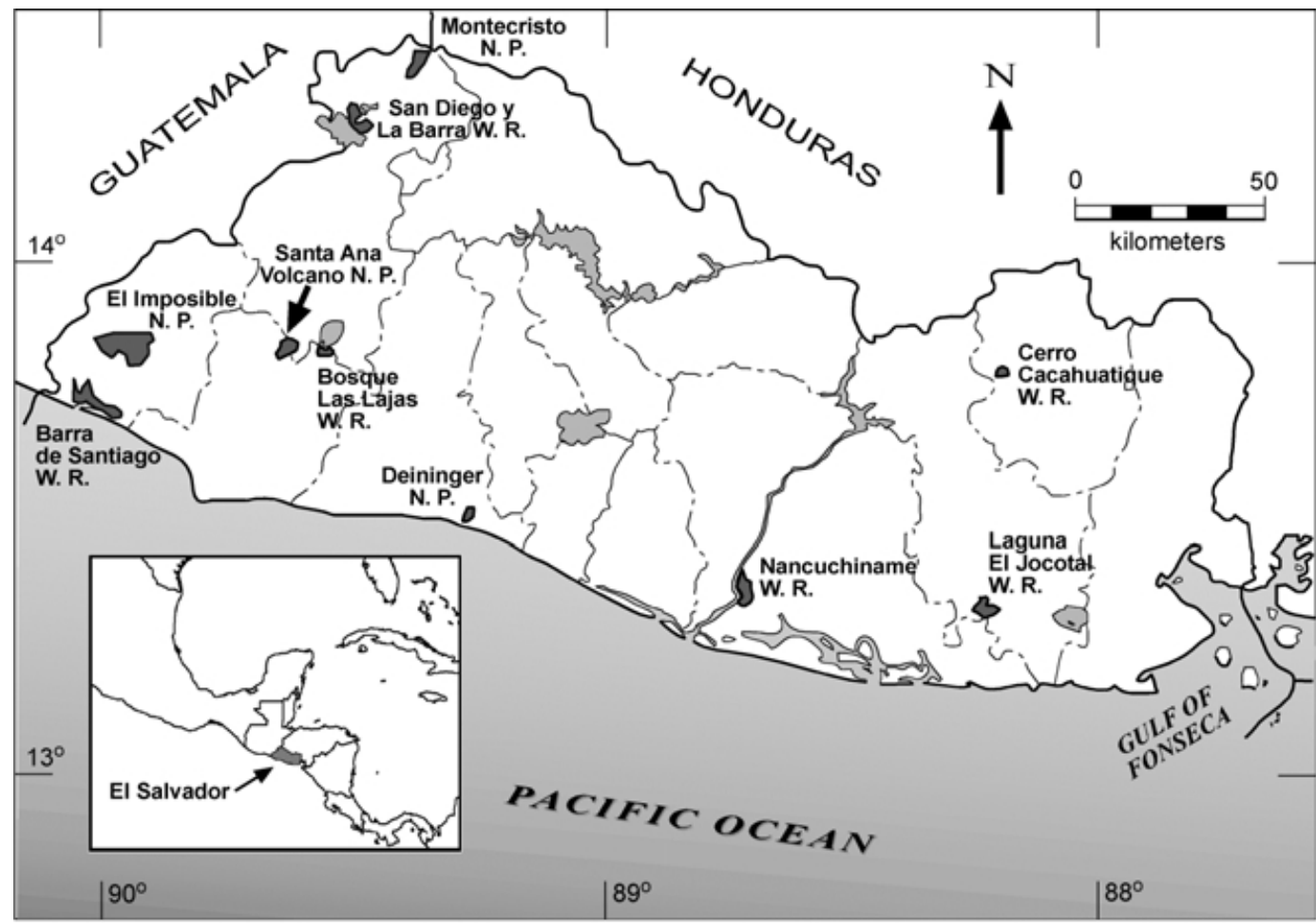

Fig. 1. Ten protected areas in El Salvador for which reasonably complete information about bird populations was available. These are also the ten largest protected areas. 
migratory birds. If a reserve could still not be selected, a third criterion was the number of regionally endemic species added to the system. For regionally endemic birds of northern Central America I used the list given by Peterson, Escalona-Segura \& Griffith (1998). A final tiebreaker criterion was the overall number of threatened bird species present at the reserve. (4) Repeat steps 2 and 3 until all reserves have been added to the system.

\section{RESULTS}

Montecristo National Park (cloud forest, pine-oak forest) was ranked first, because it protected $112(42 \%)$ nationally threatened bird species. El Imposible National Park (tropical semi-deciduous and evergreen forests) was second; El Imposible combined with Montecristo protected 167 species (62\%). Third was Laguna El Jocotal wildlife refuge (freshwater marsh habitat), adding 40 species and increasing the total to 207 (77\%). Adding Barra de Santiago wildlife refuge (mangroves and coastal estuaries) protected an additional 15 species, raising the total to $222(83 \%)$. The fifth reserve was San Diego y La Barra (dry deciduous forest and freshwater lake), adding seven species. Walter Thilo Deininger National Park (dry semi-deciduous forest) was sixth, adding three species. Seventh was Cerro Cacahuatique reserve (tropical semi-deciduous forest and oak forest), adding two species. The eighth position was tied three ways, but the tiebreaker criteria selected Las Lajas reserve, a tropical evergreen and semi-deciduous forest that forms part of the Complejo San Marcelino wildlife refuge, adding one regionally endemic species. The ninth position was also tied, but the final tiebreaker criterion selected the Santa Ana Volcano, a cloud forest and xeric scrub habitat reserve, that protected 49 threatened species. The tenth position, the Nancuchiname gallery forest reserve, protected only 38 . The whole combina- tion protected 236 species, $88 \%$ of El Salvador's threatened birds (Table 2).

Four of the ten protected areas stood out as having relatively large numbers of threatened species found at no other park; such species are referred to hereafter as 'singletons' (Table 2). Ranking area priorities by singleton threatened species, but not by overall richness, gave the same order as the complementarity analysis for the top five priority areas (Fig. 2). For resident species, singletons numbered 38, 20,13, ten, and five, respectively. Laguna El Jocotal stood out as especially important for migrants, with six migratory singletons (Table 2). All ten areas included at least one species that received protection at no other area, but 31 threatened species ( 28 resident, three migrant) were not found at any of the ten areas, indicating that more protected areas are needed.

The area with the most regionally endemic birds was Montecristo National Park (Table 3). Only Montecristo and Las Lajas forest protected endemic species that bred at no other protected areas in El Salvador (singletons). Montecristo was followed by Santa Ana Volcano in overall richness of regionally endemic species.

\section{DISCUSSION}

The complementarity analysis demonstrated the relative importance of four existing protected areas which, combined, provided protection for $83 \%$ of El Salvador's threatened bird species in a space of less than 7600 ha. These four areas each protected different sectors of the country's avifauna, and thus all should be of the highest conservation priority. Increasing the size of these areas should be planned, as their current sizes may not be large enough to maintain viable populations of any species for the long term. The relatively small populations of birds and other vertebrates that can live in such small reserves make virtually all of the threatened

Table 1. The ten largest El Salvador protected areas include eight principal habitat types, totaling 11,310 ha ( $0.54 \%$ of El Salvador).

\begin{tabular}{llr}
\hline Protected area & Habitat & Estimated area (ha) \\
\hline Barra de Santiago wildlife refuge & Mangrove forest & $1550^{1}$ \\
& Tropical semi-deciduous forest & $233^{2}$ \\
Cerro Cacahuatique wildlife refuge & Tropical semi-deciduous forest and scrub & $110^{3}$ \\
& Oak forest & $10^{3}$ \\
El Imposible National Park & Tropical semi-deciduous forest and scrub & $1600^{4}$ \\
& Tropical evergreen forest & $2400^{4}$ \\
El Jocotal Lagoon wildlife refuge & Freshwater marsh & $300^{3}$ \\
Las Lajas forest (part of Complejo San Marcelino wildlife refuge) & Tropical evergreen forest & $400^{5}$ \\
Montecristo National Park & Cloud forest & $300^{6}$ \\
& Pine-oak forest & $1000^{6}$ \\
Nancuchiname Forest wildlife refuge & Tropical semi-deciduous forest & $200^{6}$ \\
San Diego y La Barra wildlife refuge & Tropical semi-deciduous floodplain forest & $1100^{3}$ \\
Santa Ana Volcano (Cerro Verde and Los Andes National Parks) & Tropical deciduous forest & $687^{3}$ \\
& Cloud forest & $488^{2}$ \\
Walter Thilo Deininger National Park & Tropical montane scrub & $200^{2}$ \\
Totals & Tropical semi-deciduous forest and scrub & $732^{2}$ \\
\hline
\end{tabular}

${ }^{1}$ Salazar de Jurado et al., 1995

${ }^{2}$ Secretaría Ejecutiva de Medio Ambiente, 1994

${ }^{3}$ Néstor Herrera, pers. comm.

${ }^{4}$ Enrique Fuentes, SalvaNATURA, pers. comm.

${ }^{5}$ Komar \& Herrera, 1995

${ }^{6}$ Komar, 2002 
Table 2. Both richness of threatened species and the presence of singleton threatened species indicated that the two largest national parks are the most important conservation areas in El Salvador.

\begin{tabular}{|c|c|c|c|c|c|}
\hline Protected area & $\begin{array}{l}\text { Ranking by } \\
\text { complementarity }\end{array}$ & $\begin{array}{l}\text { Threatened } \\
\text { resident } \\
\text { species }\end{array}$ & $\begin{array}{l}\text { Singleton } \\
\text { resident } \\
\text { species }\end{array}$ & $\begin{array}{l}\text { Threatened } \\
\text { migratory } \\
\text { species }\end{array}$ & $\begin{array}{l}\text { Singleton } \\
\text { migratory } \\
\text { species }\end{array}$ \\
\hline Montecristo National Park & 1 & 108 & 36 & 6 & 0 \\
\hline El Imposible National Park & 2 & 94 & 20 & 10 & 0 \\
\hline El Jocotal Lagoon wildlife refuge & 3 & 32 & 6 & 20 & 6 \\
\hline Barra de Santiago wildlife refuge & 4 & 44 & 8 & 12 & 2 \\
\hline San Diego y La Barra wildlife refuge & 5 & 45 & 1 & 16 & 4 \\
\hline Walter Thilo Deininger National Park & 6 & 46 & 2 & 5 & 0 \\
\hline Cerro Cacahuatique wildlife refuge & 7 & 49 & 2 & 8 & 0 \\
\hline Las Lajas (Complejo San Marcelino wildlife refuge) & 8 & 41 & 1 & 4 & 0 \\
\hline \multicolumn{6}{|l|}{ Santa Ana Volcano complex (Cerro Verde and } \\
\hline Los Andes National Parks) & 9 & 48 & 1 & 1 & 0 \\
\hline Nancuchiname Forest wildlife refuge & 10 & 30 & 1 & 8 & 0 \\
\hline
\end{tabular}

Table 3. Distribution of El Salvador's 18 regionally endemic bird species. Fifteen breed in Montecristo National Park, more than in any other protected area $(1=$ present, $0=$ absent, bold indicates present in only one area)

Protected areas

Endemic species

White-bellied chachalaca Ortalis leucogastra

Highland guan Penelopina nigra

Ocellated quail Cyrtonyx ocellatus

Pacific parakeet Aratinga strenua

Fulvous owl Strix fulvescens

Rufous sabrewing Campylopterus rufus

Green-throated mountain-gem Lampornis viridipallens

Slender sheartail Doricha enicura

Wine-throated hummingbird Atthis ellioti

Blue-throated motmot Aspatha gularis

Belted flycatcher Xenotriccus callizonus

Bushy-crested jay Cyanocorax melanocyaneus

Black-throated jay Cyanolyca pumilo

Black-capped swallow Notiochelidon pileata

Rufous-browed wren Troglodytes rufociliatus

Rufous-collared robin Turdus rufitorques

Blue-and-white mockingbird Melanotis hypoleucus

Bar-winged oriole Icterus maculialatus

Endemic species present

Singleton endemics present

\begin{tabular}{rrrrrrrrrr}
\multicolumn{10}{c}{ Protected areas ${ }^{1}$} \\
\hline B & C & D & E & J & L & M & N & S & V \\
\hline 1 & 1 & 1 & 1 & 1 & 1 & 1 & 1 & 1 & 0 \\
0 & 0 & 0 & 0 & 0 & 0 & $\mathbf{1}$ & 0 & 0 & 0 \\
0 & 0 & 0 & 0 & 0 & 0 & 0 & 0 & 0 & 0 \\
0 & 0 & 0 & 0 & 0 & $\mathbf{1}$ & 0 & 0 & 0 & 0 \\
0 & 0 & 0 & 0 & 0 & 0 & $\mathbf{1}$ & 0 & 0 & 0 \\
0 & 0 & 0 & 1 & 0 & 0 & 0 & 0 & 0 & 1 \\
0 & 0 & 0 & 0 & 0 & 0 & 1 & 0 & 0 & 1 \\
0 & 0 & 0 & 0 & 0 & 0 & 1 & 0 & 0 & 1 \\
0 & 0 & 0 & 0 & 0 & 0 & 1 & 0 & 0 & 1 \\
0 & 0 & 0 & 0 & 0 & 0 & $\mathbf{1}$ & 0 & 0 & 0 \\
0 & 0 & 0 & 0 & 0 & 0 & $\mathbf{1}$ & 0 & 0 & 0 \\
0 & 1 & 1 & 1 & 0 & 1 & 1 & 0 & 0 & 1 \\
0 & 0 & 0 & 0 & 0 & 0 & $\mathbf{1}$ & 0 & 0 & 0 \\
0 & 0 & 0 & 0 & 0 & 0 & $\mathbf{1}$ & 0 & 0 & 0 \\
0 & 0 & 0 & 0 & 0 & 0 & 1 & 0 & 0 & 1 \\
0 & 0 & 0 & 0 & 0 & 0 & 1 & 0 & 0 & 1 \\
0 & 1 & 0 & 0 & 0 & 0 & 1 & 0 & 0 & 1 \\
0 & 1 & 0 & 1 & 0 & 1 & 1 & 0 & 0 & 1 \\
1 & 4 & 2 & 4 & 1 & 4 & 15 & 1 & 1 & 9 \\
0 & 0 & 0 & 0 & 0 & 1 & 6 & 0 & 0 & 0
\end{tabular}

${ }^{1}$ B = Barra de Santiago W. R., C = Cerro Cacahuatique W. R., D = Deininger N. P., E = El Imposible N. P., J = Laguna El Jocotal W. R., L = Bosque Las Lajas W. R., M = Montecristo N. P., N = Bosque Nancuchiname W. R., S = San Diego y La Barra W. R., V = Santa Ana Volcano (N. P.).

species subject to high risks of local extinction in the short term (Meffe \& Carroll, 1997a).

The order of importance for the remaining areas is probably not meaningful, and could change with improvements to the bird lists for those areas. Although not indicated as of prime importance by the complementarity analysis, those areas are potentially important for maintaining genetic diversity and long-term survival of threatened species. Also, the present analysis does not reflect differences in abundance and local extinction risks for individual species among protected areas. Thus a species may have its most important population at the Santa Ana Volcano (e.g., Grallaria guatimalensis, Rhynchocyclus brevirostris and Troglodytes rufociliatus, O. Komar, unpubl. data) but not add to that area's complementarity value because those same species occur, with smaller populations, at Montecristo National Park. Thus, the 'species' may not be the most significant unit for planning the conservation of biodiversity (Meffe \&
Carroll, 1997b). Genetically, the isolated populations at the volcano may be important for conservation, and indeed at least two subspecies are endemic to the volcano (Dickey \& van Rossem, 1938). Unfortunately, avian taxonomy of the northern Central American region is not complete enough to permit an analysis at the subspecies level, and no studies of avian genetic diversity or metapopulations in El Salvador have been published.

Montecristo National Park ranked highest in importance for bird conservation in El Salvador. How important is the park on a regional scale? The park protects 2000 ha in an isolated mountain range located at the intersection of El Salvador, Guatemala and Honduras. The area has been proposed as an international biosphere reserve, yet lands in Honduras and Guatemala are not yet officially protected, or at least have no infrastructure or presence of park guards. The contiguous forested area may be as large as 20,000 ha, although a thorough analysis has not been published. Ecosystems include Central 


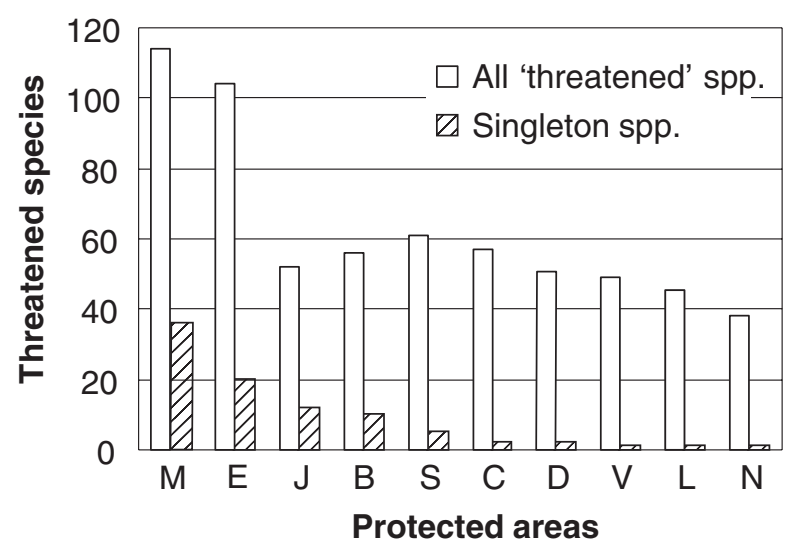

Fig. 2. Ranking area priorities by singleton threatened species, but not by all threatened species, matched ranking by complementarity (for the top five ranks). Singleton species are those that occur at a single protected area. (Key: B = Barra de Santiago W. R., C = Cerro Cacahuatique W. R., D = Deininger N. P., E = El Imposible N. P., J = Laguna El Jocotal W. R., L = Bosque Las Lajas W. R., M = Montecristo N. P., $\mathrm{N}=$ Bosque Nancuchiname W. R., $\mathrm{S}=$ San Diego y La Barra W. R., V = Santa Ana Volcano (N. P.).)

American Montane Forest, Central American Pine-Oak Forest, and Central American Pacific Dry Forest, all regionally threatened ecoregions (Dinerstein et al., 1995). The wildlife at Montecristo park benefits from the existence of adjacent forest land, but that land is not adequately protected. The park is an important reserve for nearly 100 habitat-specialist bird species of pine-oak and cloud forest habitats (Komar, 2002). Studies of humid montane habitats in northern Central America showed Montecristo National Park to be regionally important for the conservation of passalid beetles (Schuster, Cano \& Cardona, 2000) and staphylinid and curculionid beetles (Anderson \& Ashe, 2000), insect groups considered indicators for other taxa. The isolated highland area that includes Montecristo park is home to several endemic taxa that occur nowhere else in the world, including at least one plant (Zamudio, 1997), a beetle (Schuster, 1989) and a lizard (Hidalgo, 1983).

If Montecristo National Park and the surrounding forests were destroyed, the loss would have a significant impact on global biodiversity conservation, given the presence of several endemic non-avian taxa, and 15 regionally endemic bird species. Almost all of the protected areas in this analysis offer some benefits to global biodiversity conservation, through the protection of globally endangered ecosystems, locally endemic taxa (non-avian) and genetic diversity. El Imposible National Park protects a significant patch of Sierra Madre de Chiapas Moist Forest ecosystem at the eastern limit of that ecoregion, and contains several plants and trees not known from any other protected area. The Santa Ana volcano is home to endemic populations (subspecies) of birds, as is Cerro Cacahuatique (Dickey \& van Rossem, 1938).

Undisturbed natural habitat is at a premium in $\mathrm{El}$ Salvador. Only about $0.8 \%$ of the country is protected in national parks or wildlife refuges, and only half of this area has been legally declared protected (Rodríguez, 1998). The birds and wildlife that find refuge in most of these areas share them with people. The 2000 ha Montecristo National Park encompasses two villages with a population of 704 (El Salvador Park Service, unpubl. data, 1998); El Imposible National Park still has about 250 people living inside the protected zone (E. Fuentes, pers. comm.). A crucial refuge for freshwater bird species, Laguna El Jocotal wildlife refuge, is also among the most disturbed. A small town was built alongside the 1000 ha lagoon. Villagers constantly search for fish and shellfish; ranchers graze cattle all around the lagoon. Relict wooded swamplands are visited daily by firewood gatherers (pers. obs.). At present, truly protected areas are difficult to distinguish from paper parks. In some areas, park guards cannot prevent looting of natural resources. Other areas appear protected, but are privately owned, without guarantee of future conservation measures. Human disturbance issues should be major concerns of the protected areas' managers.

The present analysis has addressed bird conservation within the existing protected areas, suggesting priorities for assuring long-term protection and adequate management of selected reserves. A future analysis must address how to complete the protection of El Salvador's threatened and endangered birds, initially focusing on the distribution of the 31 unprotected species, and identifying potential reserves for these species. Significant areas of unprotected pine-oak forests exist in Chalatenango and Morazán departments (northwestern and northeastern El Salvador, near the Honduras border). The largest forest patch in El Salvador, about 22,900 ha, is the Bahía de Jiquilisco mangrove estuary (Salazar de Jurado, Guillén Morales \& Ulloa, 1995). Although local laws protect mangroves and wildlife, the area is not declared a protected area and is not managed as one. In addition to $\mathrm{El}$ Salvador's natural habitats, corridor lands that serve to connect wildlife populations in protected areas may be important for conservation. Shaded coffee plantations may play such a role for some species. Several locally threatened species (Dendrortyx leucophrys, Dactylortyx thoracicus and Xiphorhynchus flavigaster among others) regularly occur in some of El Salvador's coffee plantations, even at distances greater than $5 \mathrm{~km}$ from natural forest habitat (O. Komar, unpubl. data).

Six of the unprotected bird species have not been reported in El Salvador since the 1940s (Dickey \& van Rossem, 1938; Marshall, 1943), and may now be extirpated. These are jabiru (Jabiru mycteria), ocellated quail (Cyrtonyx ocellatus), scarlet macaw (Ara macao), unspotted saw-whet owl (Aegolius ridgwayi), royal flycatcher (Onychorhynchus coronatus) and Steller's jay (Cyanocitta stelleri). The ornate hawk-eagle (Spizaetus ornatus) was last reported in the early 1980s (Thurber et al., 1987). Owing to small reserve sizes, all threatened birds in El Salvador need additional protection. Other countries in Central America have declared $10-35 \%$ of their territories as protected lands, while El 
Salvador has less than 1\% (Rodríguez, 1998). I suggest that the biodiversity present in El Salvador merits expanding protected areas drastically. Increasing protected areas to $10 \%$ would benefit wildlife greatly, even if much of the newly protected area is highly disturbed initially. Over time, disturbed habitats will recuperate. Unfortunately, the socio-political challenges encountered to meet that goal will be daunting.

From time to time, conservation priorities in a protected area system should be re-evaluated. Because of small population sizes, rapidly changing climate and other factors, birds living in the protected areas should be monitored, and other faunal groups should be inventoried. Various studies have shown that individual taxa are poor indicators for other taxa (Dobson et al., 1997; van Jaarsveld et al., 1998), so conservation analyses should be based on many taxa. Perhaps the priorities for bird conservation are different from priorities for the conservation of reptiles, mammals, plants or other groups. None the less, single-taxon studies are frequent in the literature for various reasons (examples include Cofré \& Marquet, 1999; Peterson et al., 2000a; Schuster, et al., 2000). Kark et al. (1999) suggested conservation priorities based on the distribution of a single species. In the present case, species lists for non-bird taxa were not available. Land managers and biologists in $\mathrm{El}$ Salvador's protected areas should conduct inventories of many taxa to permit less biased analyses of priorities for resource allotment.

\section{Acknowledgements}

I thank the many people who assisted with collection of field data, and especially Néstor Herrera for providing unpublished data, and the personnel of the Ministerio de Medio Ambiente y Recursos Naturales in El Salvador for supporting fieldwork over the last seven years. I am grateful to A. Townsend Peterson, Jim Sanderson and Mary Wisz for helpful comments and suggestions. This research was supported by a Madison A. and Lila Self Graduate Research Fellowship at the University of Kansas, and by a National Science Foundation Graduate Research Fellowship.

\section{REFERENCES}

Anderson, R. S. \& Ashe, J. S. (2000). Leaf litter inhabiting beetles as surrogates for establishing priorities for conservation of selected tropical montane cloud forests in Honduras, Central America (Coleoptera; Staphylinidae, Curculionidae). Biodiv. Conserv. 9: 617-653.

Cofré, H. \& Marquet, P. A. (1999). Conservation status, rarity, and geographic priorities for conservation of Chilean mammals: an assessment. Biol. Conserv. 88: 53-68.

Daugherty, H. E. (1972). The impact of man on the zoogeography of El Salvador. Biol. Conserv. 4: 273-278.

Dickey, D. R. \& van Rossem, A. J. (1938). The birds of El Salvador. Field Mus. Nat. Hist. Zool. Ser. 23: 1-609.

Dinerstein, E., Olson, D. M., Graham, D. J., Webster, A. L., Primm, S. A., Bookbinder, M. P. \& Ledec, G. (1995). A conservation assessment of the terrestrial ecoregions of Latin America and the Caribbean. Washington, DC: The World Bank.
Dobson, A. P., Rodríguez, J. P., Roberts, W. M. \& Wilcove, D. S. (1997). Geographic distribution of endangered species in the United States. Science 275: 550-553.

Dueñas, C., Wilson, L. D. \& McCranie, J. R. (2001). A list of the amphibians and reptiles of El Salvador, with notes on additions and deletions. In Mesoamerican herpetology: systematics, zoogeography, and conservation: 93-99. Johnson, J. D., Webb, R. G. \& Flores-Villela, O. A. (Eds). El Paso: The University of Texas at El Paso.

Hidalgo, H. (1983). Two new species of Abronia (Sauria: Anguidae) from the cloud forests of El Salvador. Occ. Pap. Mus. Nat. Hist. Univ. Kans. 105: 1-11.

Hilton-Taylor, C. (Compiler) (2000). 2000 IUCN Red List of Threatened Species. Gland, Switzerland and Cambridge: IUCN. Johnson, J. D. (2001). A brief history of Mesoamerican herpetology. In Mesoamerican herpetology: systematics, zoogeography, and conservation: 1-9. Johnson, J. D., Webb, R. G. \& Flores-Villela, O. A. (Eds). El Paso: The University of Texas at El Paso.

Kark, S., Alkon, P. U., Safriel, U. N. \& Randi, E. (1999). Conservation priorities for chukar partridge in Israel based on genetic diversity across an ecological gradient. Conserv. Biol. 13: $542-552$.

Kilian, N. \& Smalla, B. (2001). Ageratum salvanaturae (Eupatorieae, Compositae), a new species from the National Park El Imposible, Ahuachapán, El Salvador. Willdenowia 31: 137-140.

Kirkpatrick, J. B. (1983). An iterative method for establishing priorities for the selection of nature reserves: an example from Tasmania. Biol. Conserv. 25: 127-134.

Komar, O. (1998). Avian diversity in El Salvador. Wilson Bull. 110: 511-533.

Komar, O. (2000). Checklist of the birds of Montecristo National Park, El Salvador. San Salvador: Fundación Ecológica de El Salvador-SalvaNATURA.

Komar, O. (2002). Birds of Montecristo National Park, El Salvador. Ornitología Neotropical 13: 167-93.

Komar, O. \& Domínguez, J. P. (2001). Lista de aves de El Salvador. San Salvador: Fundación Ecológica de El Salvador-SalvaNATURA.

Komar, O. \& Herrera, N. (1995). Avian diversity at El Imposible National Park and San Marcelino wildlife refuge, El Salvador. Working Paper 4. Bronx, New York: Wildlife Conservation Society.

Komar, O. \& Rodríguez, W. (1995). Evaluación preliminar del hábitat y las aves del área natural San Diego y La Barra, El Salvador. In Avian diversity at El Imposible National Park and San Marcelino wildlife refuge, El Salvador: 69-76. Komar, O. \& Herrera, N. (Eds). Working Paper 4. Bronx, New York: Wildlife Conservation Society.

Marshall, J. T., Jr. (1943). Additional information concerning the birds of El Salvador. Condor 45: 21-33.

Meffe, G. K. \& Carroll, C. R. (1997a). Conservation reserves in heterogeneous landscapes. In Principles of conservation biology, second edition: 305-343. Meffe, G. K. \& Carroll, C. R. (Eds). Sunderland, MA: Sinauer Associates.

Meffe, G. K. \& Carroll, C. R. (1997b). Genetics: conservation of diversity within species. In Principles of conservation biology, second edition: 161-201. Meffe, G. K. \& Carroll, C. R. (Eds). Sunderland, MA: Sinauer Associates.

Ministerio de Medio Ambiente y Recursos Naturales (2000). Estrategia nacional de diversidad biológica. San Salvador: Ministerio de Medio Ambiente y Recursos Naturales.

Owen, J. G., Knox, J. \& Baker, R. (1991). Annotated checklist of land mammals of El Salvador. Occ. Pap. Mus. Texas Tech. Univ. 139: 1-17.

Peterson, A. T., Ball, L. G. \& Brady, K. W. (2000a). Distribution of the birds of the Philippines: biogeography and conservation priorities. Bird Conserv. Int. 10: 149-167. 
Peterson, A. T., Egbert, S. L., Sánchez-Cordero, V. \& Price, K. P. (2000b). Geographic analysis of conservation priority: endemic birds and mammals in Veracruz, Mexico. Biol. Conserv. 93: 85-94.

Peterson, A. T., Escalona-Segura, G. \& Griffith, J. A. (1998). Distribution and conservation of birds of northern Central America. Wilson Bull. 110: 534-543.

Ramírez-Sosa, C. \& Komar, O. (1996). Plan para la conservación de la biodiversidad del Parque Nacional El Imposible. 30 June 1996. Colección Consultoría. San Salvador: Green Project/ USAID.

Rodríguez, J. (1998). State of environment and natural resources in Central America 1998. San José, Costa Rica: Central American Commission on Environment and Development.

Salazar de Jurado, M., Guillén Morales, R. \& Ulloa, J. 1995. Estimación de las áreas de manglares en los principales bosques salados de El Salvador, mediante el uso de teledetección satelital para 1987-88 y 1994. In Simposium Ecosistema de manglares en el Pacífico Centroamericano y sus recursos de postlarvas de camarone peneidos, San Salvador, 8-11 Noviembre 1994: 203-209. Zamorano, J. (Ed.). San Salvador: PRADEPESCA/ Unión Europea.

Schuster, J. C. (1989). Petrejoides salvadorae, sp. nov. (Coleoptera: Passalidae) from El Salvador. Fla. Entomol. 72: 693-696.
Schuster, J. C., Cano, E. B. \& Cardona, C. (2000). Un método sencillo para priorizar la conservación de bosques nubosos de Guatemala, usando Passalidae (Coleoptera) como organismos indicadores. Acta Zool. Mex. 80: 197-209.

Secretaría Ejecutiva de Medio Ambiente (1994). Plan y estrategia del Sistema Salvadoreño de Areas Protegidas (SISAP). San Salvador: Ministerio de Agricultura y Ganadería.

Thurber, W. A., Serrano, J. F., Sermeño, A. \& Benítez, M. (1987). Status of uncommon and previously unreported birds of El Salvador. Proc. West. Found. Vert. Zool. 3: 109-293.

van Jaarsveld, A. S., Freitag, S., Chown, S. L., Muller, C., Koch, S., Hull, H., Bellamy, C., Krüger, M., Endrödy-Younga, S., Mansell, M. W. \& Scholtz, C. H. (1998). Biodiversity assessment and conservation strategies. Science 279: 2106-2108.

Williams, P., Gibbons, D., Margules, C., Rebelo, A., Humphries, C. \& Pressey, R. (1996). A comparison of richness hotspots, rarity hotspots, and complementary areas for conserving diversity of British birds. Conserv. Biol. 10: 155-174.

Winker, K. (1998). Recent geographic trends in neotropical avian research. Condor 100: 764-768.

Zamudio, S. (1997). Una especie nueva de Pinguicula (Lentibulariaceae) de Centroamérica. Acta Bot. Mex. 40: 65-69.

APPENDIX 1

Distribution of nationally threatened birds in ten protected areas in El Salvador

Protected areas ${ }^{1,2}$

\begin{tabular}{|c|c|c|c|c|c|c|c|c|c|c|}
\hline Species & $\mathrm{B}$ & $\mathrm{C}$ & $\mathrm{D}$ & $\mathrm{E}$ & $\mathrm{J}$ & $\mathrm{L}$ & M & $\mathrm{N}$ & $\mathrm{S}$ & $\mathrm{V}$ \\
\hline \multicolumn{11}{|l|}{$\underline{\text { Resident species }}$} \\
\hline Crypturellus cinnamoтеus & $\mathrm{p}$ & $\mathrm{x}$ & $\mathrm{x}$ & $\mathrm{x}$ & & $\mathrm{x}$ & $\mathrm{x}$ & & $\mathrm{x}$ & $\mathrm{p}$ \\
\hline Tachybaptus dominicus & & & & & $\mathbf{x}$ & $\mathrm{p}$ & $\mathrm{p}$ & & & \\
\hline Podilymbus podiceps & & & & & $\mathrm{x}$ & & & & $\mathrm{x}$ & \\
\hline Phalacrocorax brasilianus & $\mathrm{p}$ & & & & $\mathrm{x}$ & & & & $\mathrm{x}$ & \\
\hline Anhinga anhinga & $\mathrm{x}$ & & & & $\mathrm{x}$ & & & & & \\
\hline Botaurus pinnatus & & & & & $\mathbf{x}$ & & & & & \\
\hline Ixobrychus exilis & & & & & $\mathbf{x}$ & & & & & \\
\hline Tigrisoma mexicanum & $\mathbf{x}$ & & & & & & & & & \\
\hline Ardea alba & $\mathrm{x}$ & & & & $\mathrm{x}$ & & & & $\mathrm{x}$ & \\
\hline Egretta tricolor & $\mathbf{x}$ & & & & & & & & & \\
\hline Cochlearius cochlearius & $\mathbf{x}$ & & & & & & & & & \\
\hline Eudocimus albus & $\mathbf{x}$ & & & & & & & & & \\
\hline Sarcoramphus papa & & $\mathrm{p}$ & & $\mathbf{x}$ & & & $\mathrm{p}$ & & & \\
\hline Dendrocygna bicolor & $\mathrm{p}$ & & & & $\mathbf{x}$ & & & & & \\
\hline Cairina moschata & $\mathrm{x}$ & & & & $\mathrm{x}$ & & & $\mathrm{x}$ & & \\
\hline Nomonyx dominicus & & & & & $\mathrm{x}$ & & & & $\mathrm{x}$ & \\
\hline Leptodon cayanensis & $\mathrm{p}$ & & $\mathrm{x}$ & $\mathrm{x}$ & & & & & & \\
\hline Chondrohierax uncinatus & & & & $\mathbf{x}$ & & & & & & \\
\hline Rostrhamus sociabilis & & & & & $\mathrm{x}$ & & & & $\mathrm{x}$ & \\
\hline Ictinia plumbea & $\mathrm{x}$ & & & $\mathrm{x}$ & & & & & & \\
\hline Busarellus nigricollis & $\mathbf{x}$ & & & & & & & & & \\
\hline Accipiter striatus chionogaster & & $\mathrm{p}$ & & & & & $\mathbf{x}$ & & & \\
\hline Geranospiza caerulescens & $\mathrm{p}$ & & $\mathrm{x}$ & & & & & $\mathrm{x}$ & $\mathrm{x}$ & \\
\hline Leucopternis albicollis & & & & $\mathbf{x}$ & & & & & & \\
\hline Asturina nitida & $\mathrm{x}$ & $\mathrm{x}$ & $\mathrm{x}$ & $\mathrm{x}$ & & & $\mathrm{x}$ & & $\mathrm{x}$ & \\
\hline Buteogallus anthracinus & $\mathrm{x}$ & $\mathrm{x}$ & $\mathrm{x}$ & $\mathrm{x}$ & & & & & $\mathrm{x}$ & \\
\hline Buteogallus subtilis & $\mathbf{x}$ & & & & & & & & & \\
\hline Buteogallus urubitinga & $\mathrm{x}$ & & $\mathrm{p}$ & $\mathrm{x}$ & & & $\mathrm{p}$ & $\mathrm{p}$ & & \\
\hline Parabuteo unicinctus & $\mathrm{p}$ & & & & & & & & & \\
\hline Harpyhaliaetus solitarius & & & & & & & $\mathrm{p}$ & & & \\
\hline Buteo magnirostris & $\mathrm{x}$ & & $\mathrm{x}$ & $\mathrm{x}$ & $\mathrm{x}$ & & & $\mathrm{x}$ & $\mathrm{x}$ & \\
\hline Buteo brachyurus & $\mathrm{p}$ & $\mathrm{x}$ & $\mathrm{x}$ & $\mathrm{x}$ & & $\mathrm{x}$ & $\mathrm{x}$ & $\mathrm{x}$ & $\mathrm{x}$ & $\mathrm{p}$ \\
\hline Buteo albicaudatus & & $\mathrm{p}$ & & & & & $\mathrm{p}$ & & $\mathrm{p}$ & \\
\hline Buteo jamaicensis & & $\mathrm{x}$ & & $\mathrm{x}$ & & $\mathrm{x}$ & $\mathrm{x}$ & & & $\mathrm{x}$ \\
\hline Spizaetus tyrannus & & & & $\mathrm{x}$ & & & & & & $\mathrm{x}$ \\
\hline Spizaetus ornatus & $\mathrm{p}$ & & & $\mathrm{p}$ & & & & & & \\
\hline Micrastur ruficollis & & $\mathrm{x}$ & & $\mathrm{x}$ & & & $\mathrm{x}$ & & & $\mathrm{x}$ \\
\hline Micrastur semitorquatus & $\mathrm{x}$ & & $\mathrm{x}$ & $\mathrm{x}$ & & $\mathrm{x}$ & $\mathrm{x}$ & $\mathrm{x}$ & $\mathrm{x}$ & \\
\hline Caracara cheriway & $\mathrm{x}$ & $\mathrm{p}$ & & $\mathrm{p}$ & $\mathrm{p}$ & & & $\mathrm{x}$ & $\mathrm{x}$ & \\
\hline
\end{tabular}


Continued

Protected areas ${ }^{1,2}$

Species

Falco sparverius tropicalis Falco rufigularis

Ortalis leucogastra

Penelope purpurascens

Penelopina nigra

Crax rubra

Dendrortyx leucophrys

Dactylortyx thoracicus

Cyrtonyx ocellatus

Laterallus ruber

Aramides axillaris

Aramides cajanea

Porzana flaviventer

Porphyrula martinica

Gallinula chloropus

Fulica americana

Aramus guarauna

Burhinus bistriatus

Charadrius wilsonia

Haematopus palliatus

Himantopus mexicanus

Sterna antillarum

Rynchops niger

Columba fasciata

Claravis pretiosa

Geotrygon albifacies

Geotrygon montana

Aratinga holochlora

Aratinga strenua

Aratinga canicularis

Ara macao

Brotogeris jugularis

Amazona albifrons

Amazona auropalliata

Coccyzus minor

Dromococcyx phasianellus

Geococcyx velox

Tyto alba

Otus cooperi

Otus trichopsis

Pulsatrix perspicillata

Bubo virginianus

Ciccaba virgata

Ciccaba nigrolineata

Strix fulvescens

Pseudoscops clamator

Aegolius ridgwayi

Chordeiles acutipennis

Nyctibius jamaicensis

Panyptila sanctihieronymi

Campylopterus rufus

Campylopterus hemileucurus

Colibri thalassinus

Abeillia abeillei

Hylocharis eliciae

Hylocharis leucotis

Amazilia cyanocephala

Amazilia cyanura

Lampornis viridipallens

Lampornis amethystinus

Lamprolaima rhami

Eugenes fulgens

Heliomaster longirostris

Heliomaster constantii

Doricha enicura

Tilmatura dupontii

Atthis ellioti

Trogon melanocephalus

Trogon violaceus

Trogon elegans

Trogon collaris

Pharomachrus mocinno

\begin{tabular}{|c|c|c|c|c|c|c|c|c|c|}
\hline B & $\mathrm{C}$ & $\mathrm{D}$ & $\mathrm{E}$ & $\mathrm{J}$ & $\mathrm{L}$ & $\mathrm{M}$ & $\mathrm{N}$ & $S$ & $\mathrm{~V}$ \\
\hline $\mathrm{x}$ & $\mathrm{x}$ & $\mathrm{x}$ & $\mathrm{x}$ & $\mathrm{x}$ & $\mathrm{x}$ & $\mathrm{X}$ & $\mathrm{x}$ & $\mathrm{x}$ & \\
\hline $\mathrm{p}$ & & & $p$ & & & & & & \\
\hline \multirow[t]{2}{*}{$\mathrm{x}$} & $\mathrm{x}$ & $\mathrm{x}$ & $\mathrm{x}$ & $\mathrm{x}$ & $\mathrm{x}$ & $\mathrm{x}$ & $\mathrm{x}$ & $\mathrm{x}$ & \\
\hline & & & $\mathbf{X}$ & & & $\mathbf{x}$ & & & $\mathrm{p}$ \\
\hline $\mathrm{p}$ & & & $\mathbf{x}$ & & & & & & \\
\hline & $\mathrm{x}$ & & & & $\mathrm{x}$ & $\mathrm{x}$ & & & $\mathrm{x}$ \\
\hline & $\mathrm{x}$ & & $\mathrm{X}$ & & $\mathrm{x}$ & $\mathrm{x}$ & & & $\mathrm{X}$ \\
\hline
\end{tabular}

$\mathrm{X}$

$\mathrm{x}$

$\mathrm{X}$

$\mathrm{x}$

$\mathrm{X}$

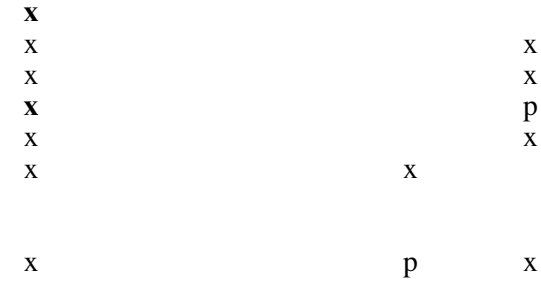

$\mathrm{p}$

$\mathrm{p}$

$\mathbf{X}$

$\mathrm{X}$

$\mathbf{X}$

$\mathrm{p}$
$\mathrm{x}$

$\mathrm{p}$

$\mathrm{x} \quad \mathrm{x}$

$\mathrm{x}$
$\mathrm{p}$

$\mathrm{p}$

$\mathbf{x}$

$x$

$\mathrm{p}$

$\mathrm{p} \quad \mathrm{x}$

$\begin{array}{ccc} & \mathrm{p} & \\ & \mathrm{x} & \mathrm{x} \\ & & \\ \mathrm{x} & \mathrm{x} & \mathrm{x} \\ \mathrm{p} & & \mathrm{x} \\ & \mathrm{x} & \mathrm{x} \\ & \mathrm{p} & \mathrm{p}\end{array}$

$$
\begin{aligned}
& \mathrm{X} \\
& \mathrm{X}
\end{aligned}
$$

$\mathrm{X}$$$
\mathrm{X}
$$$$
\mathrm{x}
$$

$\mathrm{X}$

$\mathrm{X}$

$\mathrm{X}$

$\mathrm{X}$

$\mathbf{X}$

$\mathrm{p}$

$\begin{array}{lll} & \mathrm{X} & \mathrm{X} \\ \mathrm{X} & \mathrm{X} \\ \mathrm{X} & \mathrm{X} \\ & & \mathrm{X} \\ \mathrm{X} & \mathrm{X} & \\ \mathrm{X} & & \end{array}$

$$
\mathrm{X}
$$$$
\text { p } p
$$$$
\mathrm{x} \quad \mathrm{x}
$$$$
\mathrm{X}
$$

X

$$
\text { X }
$$$$
\mathrm{x}
$$

X

$$
\begin{aligned}
& \mathrm{X} \\
& \mathrm{X} \\
& \mathrm{X} \\
& \mathrm{X}
\end{aligned}
$$




\begin{tabular}{|c|c|c|c|c|c|c|c|c|c|c|}
\hline Species & $\mathrm{B}$ & $\mathrm{C}$ & $\mathrm{D}$ & $\mathrm{E}$ & $\mathrm{J}$ & $\mathrm{L}$ & M & $\mathrm{N}$ & $\mathrm{S}$ & V \\
\hline Hylomanes momotula & & & & $\mathbf{X}$ & & & & & & \\
\hline Aspatha gularis & & & & & & & $\mathbf{x}$ & & & \\
\hline Ceryle torquata & $\mathrm{x}$ & & & & $\mathrm{x}$ & & & & $\mathrm{x}$ & \\
\hline Chloroceryle amazona & $\mathrm{p}$ & & & & & & & & $\mathbf{x}$ & \\
\hline Chloroceryle americana & $\mathrm{X}$ & & $\mathrm{x}$ & $\mathrm{x}$ & $\mathrm{x}$ & & $\mathrm{x}$ & $\mathrm{x}$ & $\mathrm{x}$ & \\
\hline Chloroceryle aenea & $\mathbf{x}$ & & & & & & & & & \\
\hline Notharchus macrorhynchos & $\mathrm{p}$ & & $\mathbf{x}$ & & & & & & & \\
\hline Aulacorhynchus prasinus & & $\mathrm{x}$ & $\mathrm{p}$ & $\mathrm{X}$ & & & $\mathrm{x}$ & & & $\mathrm{x}$ \\
\hline Pteroglossus torquatus & $\mathrm{p}$ & $\mathrm{p}$ & $\mathrm{x}$ & $\mathrm{X}$ & & $\mathrm{x}$ & $\mathrm{x}$ & $\mathrm{x}$ & & \\
\hline Melanerpes formicivorus & & $\mathrm{X}$ & & & & & $\mathrm{x}$ & & & \\
\hline Picoides villosus & & & & & & & $\mathbf{x}$ & & & \\
\hline Veniliornis fumigatus & $\mathrm{p}$ & & & $\mathrm{x}$ & & & & $\mathrm{x}$ & & \\
\hline Colaptes auratus & & & & & & & $\mathbf{x}$ & & & \\
\hline Dryocopus lineatus & $\mathrm{x}$ & $\mathrm{x}$ & $\mathrm{x}$ & $\mathrm{X}$ & & & $\mathrm{X}$ & $\mathrm{x}$ & $\mathrm{x}$ & \\
\hline Campephilus guatemalensis & $\mathrm{p}$ & $\mathrm{p}$ & $\mathrm{p}$ & $\mathrm{x}$ & & & & $\mathrm{x}$ & & \\
\hline Synallaxis erythrothorax & $\mathrm{p}$ & & $\mathrm{p}$ & $\mathbf{x}$ & & & & & & \\
\hline Anabacerthia variegaticeps & & & & & & & $\mathbf{x}$ & & & \\
\hline Automolus rubiginosus & & & & & & & $\mathbf{x}$ & & & \\
\hline Sclerurus mexicanus & & & & & & & $\mathbf{x}$ & & & \\
\hline Dendrocincla homochroa & & & & $\mathrm{x}$ & & & $\mathrm{x}$ & & & \\
\hline Sittasomus griseicapillus & & $\mathrm{X}$ & $\mathrm{p}$ & $\mathrm{x}$ & & & $\mathrm{x}$ & $\mathrm{x}$ & & \\
\hline Xiphocolaptes promeropirhynchus & & $\mathrm{p}$ & & $\mathbf{x}$ & & & & & & \\
\hline Dendrocolaptes sanctithomae & & $\mathrm{p}$ & & $\mathbf{x}$ & & & & & & \\
\hline Xiphorhynchus flavigaster & $\mathrm{x}$ & $\mathrm{X}$ & $\mathrm{x}$ & $\mathrm{x}$ & & $\mathrm{x}$ & $\mathrm{x}$ & $\mathrm{x}$ & $\mathrm{x}$ & \\
\hline Lepidocolaptes souleyetii & $\mathrm{x}$ & $\mathrm{x}$ & $\mathrm{x}$ & $\mathrm{x}$ & & & & & $\mathrm{x}$ & \\
\hline Lepidocolaptes affinis & & $\mathrm{x}$ & & & & & $\mathrm{x}$ & & & $\mathrm{x}$ \\
\hline Grallaria guatimalensis & & & & $\mathrm{x}$ & & & $\mathrm{x}$ & & & $\mathrm{x}$ \\
\hline Camptostoma imberbe & & & $\mathrm{x}$ & $\mathrm{x}$ & $\mathrm{x}$ & & & & $\mathrm{x}$ & \\
\hline Elaenia frantzii & & & & & & & $\mathrm{X}$ & & & $\mathrm{x}$ \\
\hline Mionectes oleagineus & $\mathrm{p}$ & & & $\mathbf{x}$ & & & & & & \\
\hline Zimmerius vilissimus & & & $\mathrm{x}$ & $\mathrm{x}$ & & $\mathrm{x}$ & & & & \\
\hline Oncostoma cinereigulare & $\mathrm{p}$ & & $\mathrm{p}$ & $\mathbf{x}$ & & & & & & \\
\hline Todirostrum cinereum & & & & $\mathbf{x}$ & & & & & & \\
\hline Rhynchocyclus brevirostris & & & & $\mathrm{x}$ & & & $\mathrm{X}$ & & & $\mathrm{x}$ \\
\hline Platyrinchus cancrominus & & & $\mathrm{p}$ & $\mathbf{x}$ & & & & & & \\
\hline Onychorhynchus coronatus & $\mathrm{p}$ & & & & & & & & & \\
\hline Xenotriccus callizonus & & & & & & & $\mathbf{x}$ & & & \\
\hline Mitrephanes phaeocercus & & $\mathrm{p}$ & & $\mathrm{p}$ & & & $\mathrm{p}$ & & & \\
\hline Contopus pertinax & & $\mathrm{X}$ & & & & & $\mathrm{X}$ & & & \\
\hline Contopus cinereus & $\mathrm{x}$ & $\mathrm{x}$ & $\mathrm{x}$ & $\mathrm{x}$ & & $\mathrm{x}$ & $\mathrm{X}$ & $\mathrm{X}$ & $\mathrm{x}$ & \\
\hline Empidonax albigularis & & & & $\mathbf{X}$ & & & $\mathrm{p}$ & & & \\
\hline Empidonax flavescens & & $\mathrm{X}$ & & $\mathrm{x}$ & & $\mathrm{x}$ & $\mathrm{X}$ & & & $\mathrm{x}$ \\
\hline Empidonax fulvifrons & & & & & & & $\mathrm{p}$ & & & $\mathrm{p}$ \\
\hline Sayornis nigricans & & & $\mathrm{x}$ & $\mathrm{x}$ & & & $\mathrm{X}$ & & $\mathrm{x}$ & \\
\hline Attila spadiceus & $\mathrm{x}$ & $\mathrm{p}$ & $\mathrm{x}$ & $\mathrm{x}$ & & & & & & \\
\hline Myiarchus tyrannulus & $\mathrm{p}$ & & $\mathrm{p}$ & $\mathrm{p}$ & $\mathrm{p}$ & $\mathrm{p}$ & $\mathrm{p}$ & $\mathrm{p}$ & $\mathrm{p}$ & \\
\hline Pachyramphus major & & $\mathrm{p}$ & & $\mathbf{X}$ & & & & & & \\
\hline Chiroxiphia linearis & $\mathrm{p}$ & & & $\mathrm{X}$ & & $\mathrm{x}$ & & & & \\
\hline Vireo pallens & $\mathrm{x}$ & & $\mathrm{p}$ & & $\mathrm{x}$ & & & & & \\
\hline Vireo solitarius montanus & & & & & & & $\mathbf{x}$ & & & \\
\hline Vireo leucophrys & & & & & & & $\mathrm{X}$ & & & $\mathrm{X}$ \\
\hline Vireolanius pulchellus & & & & $\mathbf{x}$ & & & & & & \\
\hline Cyanocitta stelleri & & & & & & & & & & \\
\hline Cyanocorax melanocyaneus & & $\mathrm{X}$ & $\mathrm{x}$ & $\mathrm{X}$ & & $\mathrm{x}$ & $\mathrm{x}$ & & & $\mathrm{x}$ \\
\hline Cyanolyca pumilo & & & & & & & $\mathbf{x}$ & & & \\
\hline Aphelocoma unicolor & & & & & & & $\mathbf{x}$ & & & \\
\hline Corvus corax & & $\mathrm{p}$ & & & & & $\mathrm{p}$ & & & \\
\hline Tachycineta albilinea & $\mathrm{x}$ & & & $\mathrm{p}$ & $\mathrm{x}$ & & & $\mathrm{x}$ & & \\
\hline Notiochelidon pileata & & & & & & & $\mathbf{x}$ & & & \\
\hline Certhia americana & & & & & & & $\mathbf{x}$ & & & \\
\hline Campylorhynchus zonatus & & & & & & & $\mathbf{x}$ & & & \\
\hline Salpinctes obsoletus & & & & & & & & & & $\mathbf{x}$ \\
\hline Thryothorus maculipectus & $\mathrm{p}$ & $\mathrm{x}$ & $\mathrm{X}$ & $\mathrm{X}$ & & $\mathrm{x}$ & $\mathrm{X}$ & & $\mathrm{x}$ & $\mathrm{x}$ \\
\hline Thryothorus rufalbus & $\mathrm{p}$ & & & $\mathrm{x}$ & & $\mathrm{x}$ & $\mathrm{x}$ & & & $\mathrm{x}$ \\
\hline Thryothorus pleurostictus & $\mathrm{p}$ & $\mathrm{p}$ & $\mathrm{X}$ & $\mathrm{x}$ & $\mathrm{p}$ & & & & $\mathrm{x}$ & \\
\hline Troglodytes rufociliatus & & & & & & & $\mathrm{x}$ & & & $\mathrm{x}$ \\
\hline Cistothorus platensis & & & & & $\mathrm{p}$ & & & & & \\
\hline Henicorhina leucophrys & & & & & & & $\mathbf{x}$ & & & \\
\hline Ramphocaenus melanurus & & & $\mathrm{x}$ & $\mathrm{x}$ & & & & & & \\
\hline Polioptila albiloris & $\mathrm{p}$ & & $\mathrm{x}$ & $\mathrm{x}$ & & & & & $\mathrm{x}$ & \\
\hline Sialia sialis & & $\mathrm{x}$ & & $\mathrm{p}$ & & & $\mathrm{x}$ & & & $\mathrm{x}$ \\
\hline Myadestes occidentalis & & $\mathrm{x}$ & & $\mathrm{X}$ & & & $\mathrm{x}$ & & & $\mathrm{x}$ \\
\hline Myadestes unicolor & & & & & & & $\mathbf{x}$ & & & \\
\hline
\end{tabular}


Continued Protected areas ${ }^{1,2}$

\begin{tabular}{|c|c|c|c|c|c|c|c|c|c|c|}
\hline Species & $\mathrm{B}$ & $\mathrm{C}$ & $\mathrm{D}$ & $\mathrm{E}$ & $\mathrm{J}$ & $\mathrm{L}$ & M & $\mathrm{N}$ & $\mathrm{S}$ & $\mathrm{V}$ \\
\hline Catharus aurantiirostris & & $\mathrm{x}$ & & $\mathrm{x}$ & & $\mathrm{x}$ & $\mathrm{x}$ & & & $\mathrm{x}$ \\
\hline Catharus frantzii & & & & & & & $\mathrm{x}$ & & & $\mathrm{x}$ \\
\hline Catharus dryas & & & & & & & $\mathbf{x}$ & & & \\
\hline Turdus infuscatus & & & & & & & $\mathrm{x}$ & & & $\mathrm{x}$ \\
\hline Turdus plebejus & & & & & & & $\mathbf{x}$ & & & \\
\hline Turdus assimilis & & $\mathrm{p}$ & & $\mathrm{x}$ & & & & & & $\mathrm{x}$ \\
\hline Turdus rufitorques & & & & & & & $\mathrm{x}$ & & & $\mathrm{x}$ \\
\hline Melanotis hypoleucus & & $\mathrm{x}$ & & $\mathrm{p}$ & & & $\mathrm{x}$ & & & $\mathrm{x}$ \\
\hline Peисеdramus taeniatus & & & & & & & $\mathbf{x}$ & & & \\
\hline Parula superciliosa & $\mathrm{p}$ & $\mathrm{p}$ & & $\mathrm{p}$ & & & $\mathrm{x}$ & & & $\mathrm{x}$ \\
\hline Dendroica petechia & $\mathbf{x}$ & & & & & & & $\mathrm{p}$ & & \\
\hline Dendroica graciae & & $\mathrm{p}$ & & & & & $\mathbf{x}$ & & & \\
\hline Geothlypis poliocephala & & & $\mathbf{x}$ & $\mathrm{p}$ & & & & & & \\
\hline Myioborus pictus & & $\mathrm{p}$ & & & & & $\mathbf{x}$ & & & \\
\hline Myioborus miniatus & & $\mathrm{p}$ & & $\mathrm{x}$ & & $\mathrm{x}$ & $\mathrm{x}$ & & & $\mathrm{x}$ \\
\hline Euthlypis lachrymosa & & $\mathrm{X}$ & $\mathrm{p}$ & $\mathrm{x}$ & & $\mathrm{x}$ & & & $\mathrm{x}$ & $\mathrm{p}$ \\
\hline Basileuterus culicivorus & & & & $\mathbf{x}$ & & & & & & \\
\hline Basileuterus belli & & & & & & & $\mathbf{x}$ & & & \\
\hline Chlorospingus ophthalmicus & & & & & & & $\mathbf{x}$ & & & \\
\hline Habia rubica & $\mathrm{x}$ & $\mathrm{p}$ & $\mathrm{x}$ & $\mathrm{x}$ & & $\mathrm{x}$ & $\mathrm{x}$ & $\mathrm{x}$ & & \\
\hline Habia fuscicauda & & & $\mathrm{x}$ & $\mathrm{x}$ & & $\mathrm{x}$ & & $\mathrm{x}$ & & \\
\hline Piranga flava & & & & & & & $\mathbf{x}$ & & & \\
\hline Piranga bidentata & & $\mathrm{p}$ & & & & & $\mathrm{x}$ & & & $\mathrm{x}$ \\
\hline Piranga leucoptera & & $\mathrm{x}$ & & $\mathrm{x}$ & & & $\mathrm{x}$ & & & $\mathrm{x}$ \\
\hline Euphonia hirundinacea & & & & $\mathrm{x}$ & & $\mathrm{x}$ & & & & \\
\hline Euphonia elegantissima & & $\mathrm{x}$ & & $\mathrm{x}$ & & & $\mathrm{x}$ & & & $\mathrm{x}$ \\
\hline Chlorophonia occipitalis & & & & & & $\mathrm{x}$ & $\mathrm{x}$ & & & $\mathrm{x}$ \\
\hline Amaurospiza concolor & & & & $\mathbf{x}$ & & & & & & $\mathrm{p}$ \\
\hline Haplospiza rustica & & & & & & & $\mathbf{x}$ & & & \\
\hline Diglossa baritula & & & & & & & $\mathrm{x}$ & & & $\mathrm{x}$ \\
\hline Atlapetes albinucha & & $\mathrm{x}$ & & & & & $\mathrm{x}$ & & & $\mathrm{x}$ \\
\hline Buarremon brunneinucha & & $\mathrm{x}$ & & & & & $\mathrm{x}$ & & & \\
\hline Melozone biarcuatum & & $\mathrm{x}$ & & $\mathrm{x}$ & & & & & & $\mathrm{p}$ \\
\hline Melozone leucotis & & & & $\mathrm{x}$ & & $\mathrm{x}$ & & & & $\mathrm{x}$ \\
\hline \multicolumn{11}{|l|}{ Spizella passerina } \\
\hline Saltator atriceps & & $\mathrm{x}$ & $\mathrm{x}$ & $\mathrm{x}$ & $\mathrm{x}$ & $\mathrm{x}$ & $\mathrm{x}$ & $\mathrm{x}$ & $\mathrm{x}$ & $\mathrm{x}$ \\
\hline Cyanocompsa parellina & $\mathrm{p}$ & & $\mathrm{x}$ & $\mathrm{x}$ & & $\mathrm{x}$ & & & $\mathrm{x}$ & \\
\hline Agelaius phoeniceus & $\mathrm{x}$ & & & & $\mathrm{x}$ & & & & $\mathrm{x}$ & \\
\hline Sturnella magna & $\mathrm{p}$ & & & & & & & & $\mathrm{p}$ & \\
\hline Icterus wagleri & & $\mathrm{x}$ & & $\mathrm{p}$ & & & $\mathrm{x}$ & & & \\
\hline Icterus maculialatus & & $\mathrm{x}$ & & $\mathrm{x}$ & & $\mathrm{x}$ & $\mathrm{x}$ & & & $\mathrm{x}$ \\
\hline Icterus chrysater & & $\mathrm{x}$ & & & & & $\mathrm{x}$ & & & \\
\hline Icterus pectoralis & $\mathrm{x}$ & $\mathrm{x}$ & $\mathrm{x}$ & $\mathrm{x}$ & & $\mathrm{x}$ & $\mathrm{x}$ & $\mathrm{x}$ & $\mathrm{x}$ & \\
\hline \multicolumn{11}{|l|}{ Psarocolius wagleri } \\
\hline Carduelis notata & & & & & & & $\mathbf{x}$ & & & \\
\hline Coccothraustes abeillei & & & & & & & $\mathbf{x}$ & & & \\
\hline
\end{tabular}

Migratory species

Podiceps nigricollis

Pelecanus erythrorhynchus

Botaurus lentiginosus

Ardea herodias

Egretta thula

Egretta rufescens

Nyctinassa violacea

Ajaia ajaja

Jabiru mycteria

Mycteria americana

Anas americana

Anas clypeata

Anas acuta

Anas crecca

Aythya affinis

Oxyura jamaicensis

Pandion haliaetus

Circus cyaneus

Accipiter cooperi

Buteo platypterus

Falco peregrinus

Porzana carolina

Charadrius alexandrinus

Empidonax hammondii

Vireo bellii

$\mathrm{x}$

$\mathbf{x}$

$\mathrm{x}$

$\mathrm{p}$

$\mathrm{x}$

X

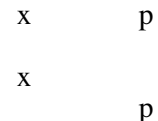

$\mathbf{x}$

$\mathrm{p}$ $\mathbf{x}$

$\mathrm{x}$

$\mathrm{x} \quad \mathrm{x}$

$\mathrm{x}$

$\mathrm{x}$

$\mathrm{x}$

$\mathrm{x}$

X

$\mathrm{x}$ 
Continued

Protected $\operatorname{areas}^{1,2}$

\begin{tabular}{|c|c|c|c|c|c|c|c|c|c|c|}
\hline Species & B & $\mathrm{C}$ & D & $\mathrm{E}$ & $\mathbf{J}$ & $\mathrm{L}$ & M & $\mathrm{N}$ & $\mathrm{S}$ & V \\
\hline Vireo flavifrons & & $\mathrm{x}$ & $\mathrm{x}$ & $\mathrm{x}$ & & $\mathrm{x}$ & & & $\mathrm{x}$ & \\
\hline Vireo philadelphicus & & $\mathrm{x}$ & & $\mathrm{x}$ & & & $\mathrm{x}$ & & & \\
\hline Petrochelidon fulva & & & $\mathrm{p}$ & $\mathrm{p}$ & $\mathbf{x}$ & & & & & \\
\hline Vermivora chrysoptera & & & & $\mathrm{x}$ & $\mathrm{x}$ & & $\mathrm{X}$ & & & \\
\hline Dendroica chrysoparia & & & & $\mathrm{p}$ & & & & & & \\
\hline Setophaga ruticilla & $\mathrm{x}$ & & & $\mathrm{p}$ & $\mathrm{x}$ & & & & & \\
\hline Protonotaria citrea & & & & & $\mathrm{x}$ & & & & $\mathrm{x}$ & \\
\hline Seiurus noveboracensis & $\mathrm{x}$ & & $\mathrm{x}$ & $\mathrm{p}$ & $\mathrm{x}$ & & & $\mathrm{x}$ & & \\
\hline Seiurus motacilla & & $\mathrm{x}$ & $\mathrm{x}$ & $\mathrm{X}$ & & & $\mathrm{x}$ & & & \\
\hline Ammodramus savannarum & & & & & & & & & $\mathbf{x}$ & \\
\hline Passerina cyanea & $\mathrm{x}$ & $\mathrm{x}$ & $\mathrm{x}$ & $\mathrm{x}$ & $\mathrm{x}$ & $\mathrm{x}$ & $\mathrm{x}$ & $\mathrm{x}$ & $\mathrm{x}$ & \\
\hline Passerina ciris & $\mathrm{x}$ & $\mathrm{x}$ & $\mathrm{x}$ & $\mathrm{x}$ & $\mathrm{x}$ & $\mathrm{x}$ & $\mathrm{x}$ & $\mathrm{x}$ & $\mathrm{x}$ & \\
\hline
\end{tabular}

Sources: Komar \& Herrera, 1995; Komar \& Rodríguez, 1995; Ramírez-Sosa \& Komar, 1996; Komar, 2000; N. Herrera, unpubl. data for Barra de Santiago and Nancuchiname; N. Herrera, R. Ibarra \& R. Rivera, unpubl. data for San Diego y La Barra; N. Herrera and R. Rivera, unpubl. report for Cerro Cacahuatique; R. Ibarra and N. Herrera, unpubl. data for Deininger; O. Komar, unpubl. data for Cerro Cacahuatique, Deininger, Laguna El Jocotal, and Santa Ana Volcano; see Methods for criteria for inclusion of species.

${ }^{1}$ B = Barra de Santiago W. R., C = Cerro Cacahuatique W. R., D = Walter Thilo Deininger N. P., E = El Imposible N. P., J = Laguna El Jocotal W. R., L = Bosque Las Lajas W. R., M = Montecristo N. P., N = Bosque Nancuchiname W. R., S = San Diego y La Barra W. R., V = Santa Ana Volcano (N. P.).

${ }^{2} \mathrm{x}=$ present, $\mathbf{x}=$ present in just one area, $\mathrm{p}=$ possible: reported but breeding now unlikely and undocumented, or, in the case of migratory birds, potentially only transient at site. 